\title{
Description of a new genus and species of the tribe Dundubiini (Hemiptera: Cicadidae: Cicadinae) from India, with taxonomic notes on Dundubiini including the description of two new subtribes
}

\author{
Young June LEE \\ Department of Ecology and Evolutionary Biology, \\ University of Connecticut, \\ 75 North Eagleville Road, Storrs, Connecticut 06269 (USA) \\ cicaderolee@gmail.com \\ David EMERY \\ Faculty of Veterinary Science, McMaster Building B14, \\ University of Sydney, Sydney, NSW. 2006 (Australia)
}

KEY WORDS

Dundubiina,

Aolina,

new subtribes,

new genus,

new species.

MOTS CLÉS

Dundubiina,

Aolina,

sous-tribus nouvelles,

genre nouveau,

espèce nouvelle.
Lee Y. J. \& Emery D. 2014. - Description of a new genus and species of the tribe Dundubiini (Hemiptera: Cicadidae: Cicadinae) from India, with taxonomic notes on Dundubiini including the description of two new subtribes. Zoosystema 36 (1): 73-80. http://dx.doi.org/10.5252/z2014n1a5

\section{ABSTRACT}

A new cicada genus and species, Zaphsa princeps n. gen., n. sp., is described from India. Four subtribes, Dundubiina Atkinson, 1886, Megapomponiina Lee n. subtr., Orientopsaltriina Lee n. subtr., and Aolina Boulard, 2012, are placed in Dudubiini Atkinson, 1886 of the subfamily Cicadinae Latreille, 1802. The new genus Zaphsa n. gen. is placed in Aolina. Mata Distant, 1906 is transferred to Oncotympanina Ishihara, 1961.

\section{RÉSUMÉ}

Description d'un nouveau genre et espèce de la tribu des Dundubiini (Hemiptera: Cicadidae: Cicadinae) de l'Inde, avec des notes taxonomiques sur les Dundubiini y compris la description de nouvelles sous-tribus.

Une nouvelle cigale Zaphsa princeps n. gen., n. sp., est décrite de l'Inde. Quatre sous-tribus, Dundubiina Atkinson, 1886, Megapomponiina Lee n. subtr., Orientopsaltriina Lee n. subtr., et Aolina Boulard, 2012, sont placés dans les Dudubiini Atkinson, 1886 de la sous-famille des Cicadinae Latreille, 1802. Le nouveau genre Zaphsa n. gen. est placé dans les Aolina. Mata Distant, 1906 est transféré dans les Oncotympanina Ishihara, 1961. 


\section{INTRODUCTION}

Duffels \& Van der Laan (1985) and Beuk (2002) treated Dundubiina Atkinson, 1886 as one of the five subtribes of the tribe Dundubiini Atkinson, 1886, together with Cosmopsaltriina Kato, 1932, Terpnosiina Kato, 1932, Leptopsaltriina Moulton, 1923, and Tosenina Amyot \& Audinet-Serville, 1843. Lee \& Hayashi (2003) proposed Dundubiina as one of the four subtribes of Dundubiini, together with Cosmopsaltriina, Cicadina Latreille, 1802, and Tosenina. Lee $(2008,2010 a)$ confirmed this concept of tribal and subtribal classification by Lee \& Hayashi (2003) but had to change the tribal name from Dundubiini to Cicadini Latreille, 1802 which has the historical priority. Based on the phylogenetic study of cicadas, Lee \& Hill (2010) added two subtribes, Psithyristriina Distant, 1905 and Leptopsaltriina Moulton, 1923 to Cicadini, with the concept and the member taxa of Dundubiina remaining the same. Lee (2011) added Oncotympanina Ishihara, 1961 to Cicadini to increase the number of its subtribes to seven. Till quite recently, Dundubiina has been treated as one of the seven subtribes of Cicadini as Lee (2013a) indicated.

However, Dundubiina is now thought to be a tribe, Dundubiini, as discussed below, which includes as many as four subtribes: Dundubiina Atkinson, 1886, Megapomponiina Lee n. subtr., Orientopsaltriina Lee n. subtr., and Aolina Boulard, 2012. This elevation from a subtribe to a tribe is in the same line with that Lee \& Emery (2013) elevated the subtribes Leptopsaltriina Moulton, 1923 to the tribe Leptopsaltriini Moulton, 1923, placing six subtribes in it.

Also, in the present paper, a new cicada species is described from India, which was found in the private collection of the second author. This new species appears closely allied to the species of the genus Kaphsa Lee, 2012 (type species: Kaphsa concordia Lee, 2012 from Thailand), but they cannot be placed in Kaphsa or its related genera because of its unique morphology as discussed below. A new genus is described here to include this new species. This new genus is placed in Aolina of Dundubiini.

\section{MATERIAL AND METHODS}

Terminology for morphological features follows that of Moulds (2005). The digital images of the male genitalia were captured using a Leica stereozoom microscope attached to a computer-assisted imaging system, Auto-Montage by Syncroscopy (Cambridge, UK), at the collection facility of the University of Connecticut. Morphological measurements were made with vernier calipers in $\mathrm{mm}$. The holotype of the new species is deposited in the Muséum national d'Histoire naturelle, Paris. The paratypes are deposited in the Australian Museum, Sydney.

\section{ABBREVIATIONS}

MNHN Muséum national d'Histoire naturelle, Paris; AMS The Australian Museum, Syndney.

\section{SYSTEMATICS}

\section{Subfamily CiCADINAE Latreille, 1802 Tribe DundubiINI Atkinson, 1886}

DiagNosis. - Pronotal collar usually dentate laterally. Wings hyaline. Timbal cover well developed. Male abdominal sternites thin and basically translucent if not coated with dark color(s) (as also seen in sister tribes like Cicadini and Leptopsaltriini). Male abdominal sternites without tubercle-like projections. Uncus usually bifurcate, but in a few cases, fused and developed to a large uncus covering ventral side of pygofer. Aedeagus thin. Basal lobe of pygofer absent or indistinct.

InCluded genera. - Dundubia Amyot \& AudinetServille, 1843, Macrosemia Kato, 1925, Crassopsaltria Boulard, 2008, Champaka Distant, 1905, Lethama Distant, 1905, Platylomia Stål, 1870, Minilomia Lee, 2013, Megapomponia Boulard, 2005, Orientopsaltria Kato, 1944, Ayesha Distant, 1905, Sinosemia Matsumura, 1927, Meimuna Distant, 1905, Sinapsaltria Kato, 1940, Sinotympana Lee, 2009, Haphsa Distant, 1905, Kaphsa Lee, 2012, Zaphsa n. gen., and Khimbya Distant, 1905 (18 genera).

Moulds (2005) placed Mata Distant, 1906 in Dundubiini, but it cannot be placed in any of the following subtribes. Mata is transferred to Oncotympanina as Mata has the following common characters: medial pronotal collar very narrow; both wings hyaline; male operculum wider than long; male opercula widely separated; timbal cover prominently globose; timbal concealed by timbal cover in dorsal view; aedeagus thin. 
Remarks. - Dundubiini by Moulds (2005) was a similar concept to Cicadini by Lee \& Hayashi (2003), Lee (2008, 2010a, 2010b, 2011, 2013a) and Lee \& Hill (2010), except for the exclusion of Cicadina (currently monotypic). This is because his Dundubiini comprised most of the genera belonging to the subtribes Dundubiina, Cosmopsaltriina, Psithyristriina, Oncotympanina, Leptopsaltriina, and
Tosenina in the sense as referred to in the first paragraph in Introduction of the present paper. The Dundubiini in the present paper is equivalent to Dundubiina by Moulds (2005) and thus should be a sister taxon of Cosmopsaltriina, Psithyristriina, Oncotympanina, Leptopsaltriina, Tosenina, and probably Cicadina, of which Leptopsaltriina was already elevated to Leptopsaltriini by Lee \& Emery (2013).

\section{Key to THE SubTribes of Dundubinin AtKinson, 1886}

1. Pronotal collar normal or broad posteriorly 2

- Pronotal collar very narrow posteriorly Aolina Boulard, 2012

2. Male operculum usually narrow and long, at least longer than wider 3

- Male operculum about as long as wide Megapomponiina Lee n. subtr.

3. Pronotal collar very broad posteriorly; male abdomen usually distinctly longer than head and thorax together Dundubiina Atkinson, 1886

- Pronotal collar about normal posteriorly; male abdomen usually about as long as head and thorax together Orientopsaltriina Lee n. subtr.

\section{Subtribe Dundubina Atkinson, 1886}

Macrosemiaria Boulard, 2003a: 266. — Boulard 2003b: 98. Nomen nudum by Articles 13.1, 16.1, and 16.2 of the International Code of Zoological Nomenclature (ICZN).

Crassopsaltriina Boulard, 2008: 7, 35. Nomen nudum by Articles 13.1, 16.1, and 16.2 of ICZN.

DiAGNOSIS. - Pronotal collar broad posteriorly. Fore wing with or without infuscations on radial and radiomedial crossveins. Male operculum obconical or uptriangular; narrow and very long, with length about or more than three times the width (with exceptions in two species in Champaka and in Minilomia). Male abdomen usually long obconical. Uncus usually bifurcate, but in a few cases, fused and developed to a large uncus covering the ventral side of the pygofer. Basal lobe of pygofer distinct or indistinct.

InCluded Genera. - Dundubia, Macrosemia, Crassopsaltria, Champaka, Lethama, Platylomia, and Minilomia.

Subtribe Megapomponina Lee n. subtr.

Megapomponiina Boulard, 2008: 7, 36. Nomen nudum by Articles 13.1, 16.1, and 16.2 of ICZN.
Type Genus. - Megapomponia Boulard, 2005, by present designation.

DiAgNOSIs. - Pronotal collar very broad posteriorly. Fore wing with infuscations on radial and radiomedial crossveins. Male operculum uptriangular, about as long as wide, extending slightly beyond posterior margin of sternite II. Male abdomen cylindrical or obconical. Uncus bifurcate. Basal lobe of pygofer absent.

INCLUDED GENERA. - Megapomponia.

\section{Subtribe ORIENTOPSALTRIINA Lee n. subtr.}

Orientopsaltraria [sic] Boulard, 2003a: 270; 2008: 7, 32. Nomen nudum by Articles 13.1, 16.1, and 16.2 of ICZN.

TyPe GENUS. - Orientopsaltria Kato, 1944, by present designation.

DiAgNOSIs. - Pronotal collar more or less broad posteriorly. Fore wing with or without infuscations on radial and radiomedial crossveins. Male operculum very long, with length about 2.5 to 3 times the central width; usually with fuscous patch medially and posteriorly. Male abdomen obconical. Uncus bifurcate. Basal lobe of pygofer absent.

INCLUDED GENERA. - Orientopsaltria and Ayesha. 
Subtribe AOLINA Boulard, 2012

Aolaria Boulard, 2003c: 172 . Nomen nudum by Articles $13.1,16.1$, and 16.2 of ICZN.

Aolina Boulard, 2012: 5.

Type GENUS. - Aola Distant, 1905 (junior synonym of Haphsa Distant, 1905).

DiAgNOSIS. — Pronotal collar narrow posteriorly. Fore wing usually with infuscations on radial and radiomedial crossveins. Male operculum basically obconical or up- triangular, with length about or less than two times the width. Male abdomen long, obconical. Uncus bifurcate. Basal lobe of pygofer absent or indistinct.

INCLUDED GENERA. - Sinosemia, Meimuna, Sinapsaltria, Sinotympana, Haphsa, Kaphsa, and Khimbya. The new genus Zaphsa n. gen. described below also belongs to Aolina.

REMARKS. - Although the present concept of the subtribe with above mentioned characters is quite different from the original concept of Aolina Boulard, 2012, the name Aolina is used as long as Aola Distant, 1905 (junior synonym of Haphsa) belongs to this group.

\section{Key to THE Genera of Aolina Boulard, 2012}

1. Body broad, shorter than 3.2 times as wide as abdominal tergite 3 2

- Body slender, longer than 3.5 times as wide as abdominal tergite 3

2. Timbal cover narrow with concave inner margin, making substantial opening between timbal cover and cruciform elevation .............................. Sinosemia Matsumura, 1927

- Timbal cover normal, only with minimal gap between timbal cover and cruciform eleva-

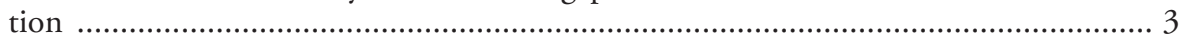

3. Male abdomen distinctly longer than head and thorax together ................................. 4

- Male abdomen slightly longer than or about as long as head and thorax together Haphsa Distant, 1905

4. Male operculum very long, extending much beyond posterior margin of sternite IV ..... Meimuna Distant, 1905

- Male operculum not extending beyond posterior margin of sternite IV 5

5. Male operculum extending beyond posterior margin of sternite III; opercula well separated Sinapsaltria Kato, 1940

- Male operculum very short, not reaching posterior margin of sternite III; opercula slightly overlapped or slightly separated Sinotympana Lee, 2009

6. Fore wing and hind wing without any infuscations along hind margin; male operculum with roundish apex; male abdomen more or less obconical 7

- Fore wing and hind wing with linear infuscation along hind margin; male operculum triangular; male abdomen long, slender, and cylindrical Khimbya Distant, 1905

7. Male opercula separated with gap much less than half as wide as operculum; uncal lobes without appendages or projections Kaphsa Lee, 2012

- Male opercula separated with gap more than half as wide as operculum; uncal lobes with a pair of projections protruding ventrally Zaphsa n. gen.

\section{Zaphsa n. gen.}

TYPE SPECIES. - Zaphsa princepsn. sp., by present designation.

ETYMOLOGY. - The generic name is an arbitrary combination of letters, suggesting that this is a genus nearly related to Kaphsa.

\section{DESCRIPTION}

Head wider than base of mesonotum. Lateral pronotal collar dentate. Wings hyaline. Fore wing basal portion of radius anterior 2 vein about half as long as longitudinal portion of radius anterior 2 vein. Male operculum much longer than broad, extending 

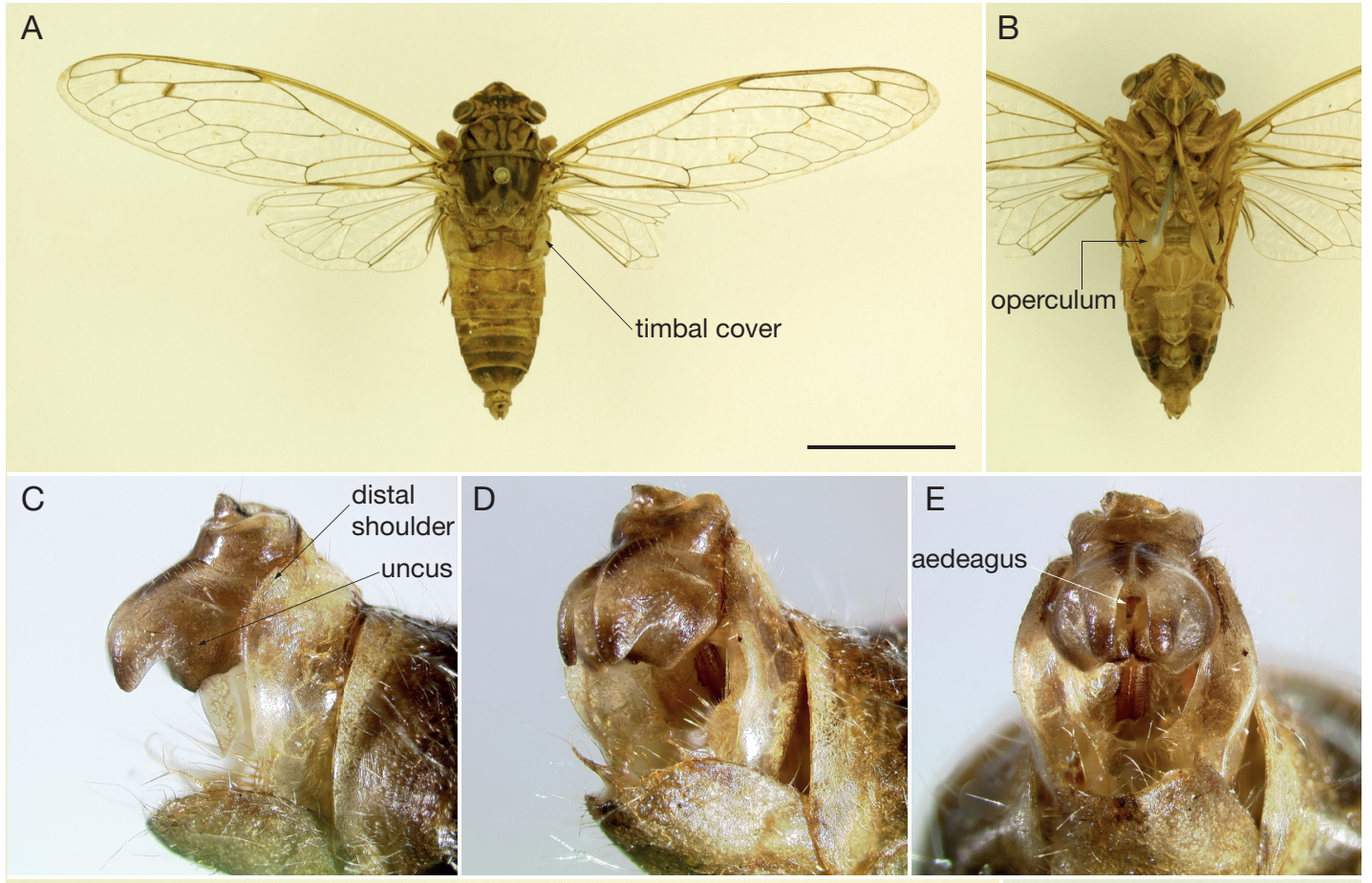

F

G
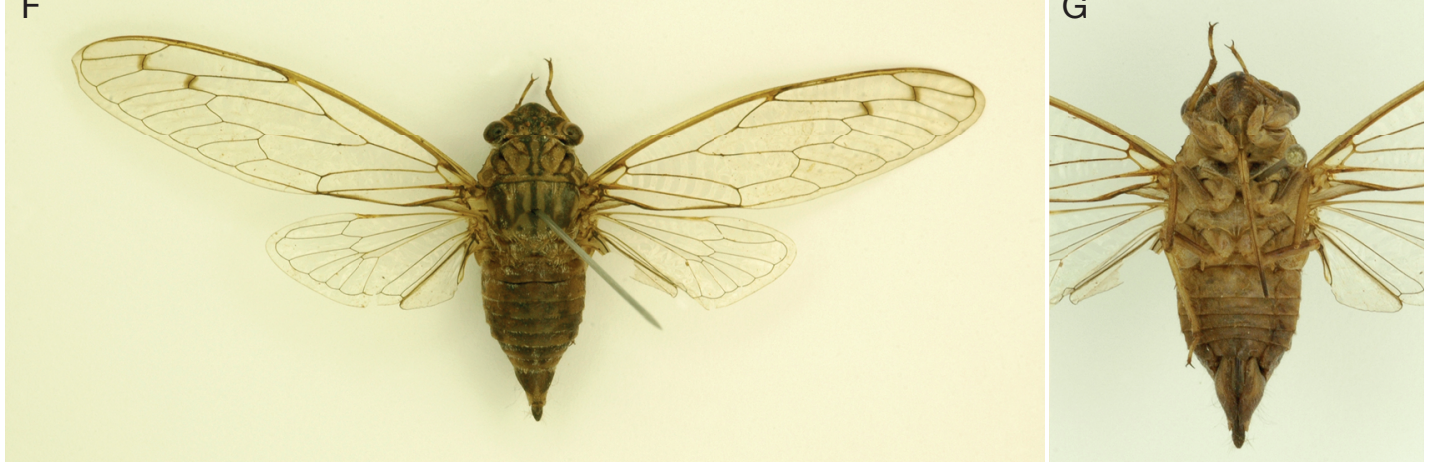

Fig. 1. - Zaphsa princeps n. gen., n. sp.: A, dorsal habitus of holotype MNHN (EH) 16437, male; B, ventral habitus of holotype MNHN (EH) 16437, male; C, lateral view of the pygofer of holotype MNHN (EH) 16437, male; D, ventrolateral view of the pygofer of holotype MNHN (EH) 16437, male; E, ventral view of the pygofer of holotype MNHN (EH) 16437, male; F, dorsal habitus of paratype, female; G, ventral habitus of paratype, female. Scale bar: $10 \mathrm{~mm}$.

much beyond posterior margin of sternite II. Male abdomen long obconical, distinctly longer than head and thorax together. Posterior margin of male abdominal tergite 3 wider than anterior margin of mesonotum. Male timbal cover well developed, about as wide as long, concealing timbal mostly but not completely in dorsal view. Distal shoulder of male pygofer rounded. Uncus bifurcate. Uncal lobes short, with a pair of projections protruding ventrally from upper part of uncal lobes. Basal lobe of pygofer small. Aedeagus thin. Ovipositor slightly protruding beyond abdominal segment 9 . 
REMARKS. - This genus is closely allied to Kaphsa (type species: Kaphsa concordia Lee, 2012 from Thailand) or Haphsa (type species: Dundubia nicomache Walker, 1850 from northern India) considering the similarity especially in fore wing venation, overall body shape, and timbal cover shape but is distinguished from Kaphsa, Haphsa, or any other genera in Aolina mainly by the following characters: male opercula separated with gap more than half as wide as operculum; uncal lobes with a pair of projections protruding ventrally from uncal lobes.

\section{Zaphsa princeps n. sp.}

(Fig. 1)

TYPe MATERIAL. - Holotype: 1 ○", "INDIA-TAMIL NADU Javadu Hills, Kavalore 600m. Jun 2006." (printed white label), MNHN (EH) 16437.

Paratypes: 2 $ᄋ$, same data as holotype (printed white

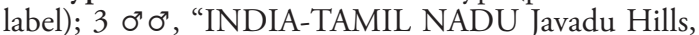
Vellore Kavalore $600 \mathrm{~m}$. Jun06." (printed white label), AMS.

ETYMOLOGY. - The specific name is the Latin masculine noun meaning "a prince" in reference to the male pygofer of this species, wearing a crown.

MeAsurements ( $\mathrm{N}=4$ MALES AND 2 FEMALES). - Median length of body: male 23.8 (22.7-25.7), female 21.3 (21.2-21.4). Median length of head and thorax together: male 10.7 (9.9-11.3), female 10.3 (10.2-10.3). Median length of abdomen: male 13.4 (13.1-14.4), female 11.1 (11.0-11.2). Width of head including eyes: male 6.8 (6.57.1), female 6.7 (6.6-6.7). Width of mesonotum: male 6.5 (6.2-6.7), female 6.6 (6.5-6.6). Width of posterior margin of abdominal tergite 3: male 6.7 (6.2-7.4), female 6.9 (6.8-7.0). Length of fore wing: male 28.1 (27.2-29.8), female 28.1 (28.0-28.2). Width of fore wing: male 8.4 (7.8-8.8), female 8.3 (8.1-8.4). Wing span: male 63.1 (60.7-66.6), female 60.8 (60.3-61.2).

\section{DESCRIPTION OF MALE}

Head

Distance between lateral ocelli and eyes about twice as wide as distance between lateral ocelli. Postclypeus much swollen to make head triangular in dorsal view. Rostrum very long, extending far beyond posterior margin of abdominal sternite II (in some specimens, up to center of abdominal sternite III). Head light brown with the following marks: large median black spot enclosing ocelli, anteriorly reaching frontoclypeal suture and posteriorly reaching posterior margin of head; a pair of large lateral fuscous spots on sides of the median spot, extending to supraantennal plates, and connected to the median spot; a pair of minute fuscous spots between the lateral spots and posterior margin of head. Antennae dark brown to fuscous. Postclypeus ochraceous with the following fuscous to brown marks: triangular spot on the most upper part near ocelli; fasciae along transverse grooves; a pair of median longitudinal fasciae, fused with each other from groove 5 to extend posteriad as single longitudinal fascia and connected with inner margins of the transverse fasciae, except for the last three (grooves 9, 10, and 11). Anteclypeus ochraceous with large brown spot on each side. Rostrum ochraceous but black apically. Lorum brown except ochraceous margin. Gena with transverse broad fuscous fascia between postclypeus and eye.

\section{Thorax}

Thorax light brown to ochraceous with dark brown to fuscous marks. Lateral pronotal collar dentate. Inner area of pronotum with the following marks: a pair of median longitudinal fasciae with anterior ends widened; a pair of rather indistinct longitudinal short fasciae between median part of paramedian fissure and posterior end of lateral fissure; a pair of fasciae along lateral fissures; a pair of curved fasciae along lateral margins of inner area, slightly extending medially. Pronotal collar with very narrow fascia along posterior and posterior half of lateral margins and two pairs of indistinct rectangular posterolateral spots. Mesonotum with the following marks: deep-colored median longitudinal fascia; a pair of small roundish spots enclosing scutal depressions; a pair of fasciae along inner parts of parapsidal sutures; a pair of longitudinal broad fasciae on lateral sigilla; a pair of very short fasciae at anterior margin of mesonotum between the above mentioned two pairs of fasciae, nearly fused with the broad fasciae on lateral sigilla in holotype. Cruciform elevation with anterior subapical parts brown in holotype. Legs ochraceous with apical part of each leg fuscous.

\section{Wings}

Wings hyaline. Fore wing with infuscation on radial and radiomedial crossveins. Radius and subcostal 
vein ochraceous. Basal membrane and hind wing jugum gray.

\section{Operculum}

Operculum ochraceous; oblique inwards towards apex, spatulate, rectangular in general with posterior corners rounded. Apex reaching about half of sternite III. Lateral margin nearly straight. Opercula apart from each other, with gap about half as wide as operculum.

\section{Abdomen}

Abdomen distinctly longer than head and thorax together. Tergites 2, 3, 4, and 5 mostly light brown, with yellowish or ochraceous lateral patches. Tergites 6,7 , and 8 dark brown to fuscous. Timbal cover ochraceous, nearly semicircular without marks. Timbal cover concealing timbal mostly but not completely in dorsal view. Ventral part of abdomen ochraceous (sternites II, III, IV, and V) to brown (sternites VI, VII, and VIII) without distinct marks.

\section{Genitalia}

Pygofer oval in ventral view. Distal shoulder rounded. Uncus bifurcate. Uncal lobes short, globose, with a pair of longitudinally parallel valvular projections protruding ventrally from upper part of uncal lobes. Basal lobe of pygofer slightly swollen smoothly rounded. Aedeagus thin.

\section{Description of female}

Operculum ochraceous; semicircular, extending slightly beyond sternite II. Abdominal sternites brown. Abdominal segment 9 largely dark brown, darker dorsally. Ovipositor sheath black, slightly protruding beyond abdominal segment 9. Dorsal beak minute.

\section{Acknowledgements}

The authors are indebted to S. A. Surender for collection of the majority of specimens studied in this paper. We are grateful to Allen F. Sanborn (Barry University, Miami Shores) and Hans Duffels (Universteit van Amsterdam, Leiden) for comments and suggestions that improved the manuscript.

\section{REFERENCES}

BeUK P. L. T. 2002. - On the systematics, phylogeny and biogeography of the cicada subtribes Dundubiina and Cosmopsaltriina (Homoptera: Cicadidae): 179323 In: Cicadas spreading by island or by spreading the wings? Historic biogeography of dundubiine cicadas of the Southeast Asian continent and archipelagos. Ph.D. dissertation, Universiteit van Amsterdam, Amsterdam: 323.

BOUlard M. 2003a. - Statut taxonomique et acoustique de quatre cigales thaillandaises, dont deux restées inédites jusqu'ici (Rhynchota, Cicadoidea, Cicadidae). Nouvelle Revue d'Entomologie (nouvelle série) 20: 259-279.

BOUlard M. 2003b. - Éthologie sonore et statut acoustique de quelques cigales thaillandaises, incluant la description de deux espèces nouvelles (Hemiptera: Auchenorhyncha, Cicadoidea, Cicadidae). Annales de la Société entomologique de France (nouvelle série) 39: 97-119.

BOULARD M. 2003c. - Contribution à la connaissance des cigales thaillandaises incluant la description de quatre espèces nouvelles (Rhynchota, Cicadoidea, Cicadidae). Revue française d'Entomologie (nouvelle série) 25: 171-201.

BOULARD M. 2008. — Les cigales thaïes. Liste actualisée incluant la description de deux nouveaux genres, de sept espèces nouvelles et les Cartes d'Identité Acoustique (CIA) de Chremistica siamensis Bregman et de Leptopsaltria samia (Walker) (Rhynchota, Cicadomorpha, Cicadidae). École pratique des hautes Études, Biologie et Évolution des Insectes 18: 1-112.

BOULARD M. 2012. — The Cicadas of Thailand. Volume 2. Taxonomy and Sonic Ethology. École pratique des hautes Études, Biologie et Évolution des Insectes 19: i-xii, 1-406, 97 colour plates. Accompanied by: 1 audio memory card.

Duffels J. P. \& VAN Der LAan P. A. 1985. - Catalogue of the Cicadoidea (Homoptera, Auchenorhyncha) 19561980. Series Entomologica, 34. Dr. W. Junk Publishers, Dordrecht: xiv+414 p.

LEE Y. J. 2008. - A checklist of Cicadidae (Insecta: Hemiptera) from Vietnam, with some taxonomic remarks. Zootaxa 1787: 1-27.

LEE Y. J. 2010a. - A checklist of Cicadidae (Insecta: Hemiptera) from Cambodia, with two new species and a key to the genus Lemuriana. Zootaxa 2487: 19-32.

LeE Y. J. 2010b. - Checklist of cicadas (Hemiptera: Cicadidae) of Luzon, Philippines, with six new species and revised keys to the species of Oncotympana Stål and Psithyristria Stål. Zootaxa 2621: 1-26.

LEE Y. J. 2011. - New genus and two new species of Oncotympanina stat. nov. (Hemiptera: Cicadidae: Cicadini) and the erection of Sonatini new tribe. Journal of Asia-Pacific Entomology 14: 167-171. 
LEE Y. J. 2013. - A new genus and species from Borneo and a new species from Java and Sumatra of Cicadini (Hemiptera: Cicadidae). Journal of Asia-Pacific Entomology 16: 369-372.

LeE Y. J. \& EMERY D. 2013. - New genera and species of Leptopsaltriini (Hemiptera: Cicadidae: Cicadinae) from India and Tibet, with the descriptions of five new subtribes. Zoosystema 35 (4): 525-535. http:// dx.doi.org/10.5252/z2013n4a6

LEE Y. J. \& HAYASHI M. 2003. — Taxonomic Review of Cicadidae (Hemiptera, Auchenorrhyncha) from Taiwan,
Part 1. Platypleurini, Tibicenini, Polyneurini, and Dundubiini (Dundubiina). Insecta Koreana 20: 149-185. LEE Y. J. \& Hill K. B. R. 2010. - Systematic revision of the genus Psithyristria Stål (Hemiptera: Cicadidae) with seven new species and a molecular phylogeny of the genus and higher taxa. Systematic Entomology 35: 277-305.

MouldS M. S. 2005. - An appraisal of the higher classification of cicadas (Hemiptera: Cicadoidea) with special reference to the Australian fauna. Records of the Australian Museum 57: 375-446.

Submitted on 10 September 2013; accepted on 25 November 2013; published on 28 March 2014. 